\title{
Expanding transboundary tourist space - The growing significance of the Augustów Canal
}

Authors' Contribution:

A Study Design

B Data Collection

C Statistical Analysis

D Data Interpretation

E Manuscript Preparation

F Literature Search

G Funds Collection

\author{
Aliaksandr Cyargeenka ${ }^{\mathrm{ABDEF}}$, Marek Więckowski ${ }^{\mathrm{ABDEF}}$ \\ Institute of Geography and Spatial Organization, \\ Polish Academy of Sciences, Warsaw, Poland
}

\section{abstract}

Background: The Belarusian-Polish borderland has great tourism potential but in the same time suffers from many restrictions, especially geopolitical ones. An overall facilitation of foreigners' trips into Belarus has facilitated the development of cross-border tourism and local resources could be used by tourists. One of the most important tourist attractions is the Augustów Canal. This article seeks to discuss changes made to one border crossing between Poland and Belarus whose location may be considered exceptional, given that it is on the Augustów Canal.

Material and methods: Analysis of historical, legal and statistical materials; cartographic analysis and fieldwork.

Results: Eased restrictions on crossing the border (i.e. 5 years of gradual, stepwise introduction of visafree regimes and zones by the Belarusian authorities) have combined with the emergence of new possibilities to travel along the Canal by bicycle or on foot to increase numbers of foreign tourists (including Poles) who take advantage of the visa-free opportunities.

Conclusions: Opportunities for the development of tourism (especially of a transboundary nature) are influenced by the simultaneous "internationalisation" and "touristification" of border crossings in Belarus's western borderland area, which serve as a tourist destination of global significance (the Augustów Canal) and/or traffic at the individual-visitor level. The factor of overriding importance encouraging steady enlargement of tourist space and its utilisation either side of the border is the so-called "BrześćGrodno Space", as a visa-free continuous corridor for tourism established in the period since November 2019. This allows for visits into western Belarus, in particular in a south-north direction. The Augustów (Augustovsky) Canal and its Rudawka-Lesnaya border crossing are expected to play a particular part in this process.

Key words: tourism, Poland, Belarus, border, border crossing, the Augustów Canal.

\section{article details}

Article statistics: Word count: 4,076; Tables: 0; Figures: 2; References: 47

Received: June 2020; Accepted: August 2020; Published: November 2020

Full-text PDF: http://www.balticsportscience.com

Copyright @ Gdansk University of Physical Education and Sport, Poland

Indexation: Celdes, Clarivate Analytics Emerging Sources Citation Index (ESCl), CNKI Scholar (China National Knowledge Infrastructure), CNPIEC, De Gruyter - IBR (International Bibliography of Reviews of Scholarly Literature in the Humanities and Social Sciences), De Gruyter - IBZ (International Bibliography of Periodical Literature in the Humanities and Social Sciences), DOAJ, EBSCO - Central \& Eastern European Academic Source, EBSCO - SPORTDiscus, EBSCO Discovery Service, Google Scholar, Index Copernicus, J-Gate, Naviga (Softweco, Primo Central (ExLibris), ProQuest - Family Health, ProQuest - Health \& Medical Complete, ProQuest - Illustrata: Health Sciences, ProQuest - Nursing \& Allied Health Source, Summon (Serials Solutions/ProQuest, TDOne (TDNet), Ulrich's Periodicals Directory/ulrichsweb, WorldCat (OCLC)

Funding: This article includes the results of research carried out under Research Project No. 2018/29/B/HS4/02417 financed by the National Science Centre of the Republic of Poland.

Conflict of interests: Authors have declared that no competing interest exists.

Corresponding author: dr hab. Marek Więckowski, prof. IGiPZ, Zakład Geografii Miast i Ludności, Instytut Geografii i Organizacji Przestrzennej PAN, Twarda 51/55, 00-818 Warsaw, Poland; e-mail: marekw@twarda.pan.pl

Open Access License: This is an open access article distributed under the terms of the Creative Commons Attribution-Non-Commercial-NoDerivatives 4.0 International (https://creativecommons.org/licenses/by-nc-nd/4.0/), which permits use, distribution and reproduction in any medium, provided the original work is properly cited, the use is non-commercial and is otherwise in compliance with the license. 


\section{INTRODUCTION}

Borders have geopolitical, historical or symbolic value and meaning. In most parts of the world, they have become more of a curiosity and a tourist attraction [1-4]. However, especially in the past, they cut transport networks, broke up social and economic networks and contributed to the isolation of border regions - in which additional problems with the development of infrastructure were then experienced, and investment was lacking. Borders were thus clear-cut barriers to flows of people.

Today, the situation along the borders of a given country may vary markedly, with conditions for the development of tourism and cross-border cooperation being highly disparate. While intra-EU border areas benefit from more favourable factors [5], areas representing external frontiers of the Union suffer from many restrictions [6, 7]. Political and institutional conditions are seen to play a decisive role as regards cross-border mobility, funding, networking, the identities of partners and the nature of joint projects $[7,8]$.

Some borders were delineated from the outset in lightly populated areas, which thus remained underdeveloped buffers and/or transition zones between neighbouring countries. At times that was a beneficial circumstance from the point of view of the protection of unique natural landscapes [9, 10].

For its part, the Belarusian-Polish borderland has very great tourism potential, but the actual development and achievement of change in this respect proved a major challenge under the circumstances, remaining very much dependent on geopolitics. Constant change would seem to be the feature typifying tourist destinations, not least as the creation and development of spaces for tourism are seen to reflect wider political, economic and social processes often driven non-locally, if manifesting themselves very locally indeed [11].

The Polish-Belarusian and Lithuanian-Belarusian borderlands now feature zones that are visa-free for the citizens of around 70 states (including the USA, and all EU Member States). These may be regarded as phenomena of an exceptional nature, by European standards and even in global terms [12]. An overall facilitation of foreigners' trips into Belarus has thus occurred, thanks to lobbying from actors that have a financial interest, be these entrepreneurs or local authorities; while the matters of the easing of the visa regime and the introduction of small-scale border traffic continue to be stalled for political and economic reasons [13]. Due to a Decree from the President of Belarus, new visa-free zones have also been appearing, and there are other regulations facilitating trips into his country by foreigners [12]. In this article, the changes introduced are exemplified by discussing one of the crossings of the Poland-Belarus border with an entirely exceptional location, along the Augustów Canal.

The Augustów Canal as specific progressing tourism recreation area can be approached from different perspectives. The most considerable and actual ones in the scientific literature are as follows: cultural and historical issues [14-16]; cross-border cooperation [2, 17-21]; touristic development and border-crossing issues [11-13, 19]; trans-boundary water management $[22,19]$; environmental protection $[9,10]$. The existing literature on the subject lacks a comprehensive view of the cross-border area of the Augustów Canal in terms of factors determining the volume of tourist traffic and increasing the importance of the Augustów Canal. This is an interdependent set of issues related to the accent of natural and historical-cultural values, the appearance and extension of the regional visafree zone on the Belarusian side, the evaluation of the procedure of crossing borders (for both EU and Belarus citizens) together with the analysis of tourist dynamics, as well as development of local touristic and border infrastructure. 


\section{METHODOLOGY}

In order to understand the processes in the transboundary area around the Augustów Canal, a multi-scalar approach was chosen. It is based on using multi-scalar (level) lens and generally has multidisciplinary features [22-24]. Firstly, the time (historical) factor was applied with a view to better understanding of the preconditions of the ensuing activities and results. Secondly, multi-scalar analysis uses both local (crossing border and touristic infrastructure, trans-border initiatives), within-country (low regulations, Grodno visa-free zone), many-sided (Belarus-Poland-EU relations, visa conditions) and global (UNESCO heritage) contexts. Actually, there is interdependence, intersection and even recurrence between these closely intertwined scales.

In addition, the statistical data were analysed, which were received from the Polish Border Guard as table in Excel software. The needed information for linear figure creation was extracted through data separation and ordering according to next criteria - border crossing point (Rudawka-Lesnaya), years (from opening in 2005 until 2018), citizenship (Polish), way of traffic (departure). On 1th of July 2019 authors crossed the border point situated on the Augustów Canal and came back as a tourist pedestrian as part of fieldwork using the participatory method. On the one hand, the purpose was to observe "in a natural way" the circumstances in the area - infrastructure, natural values, etc. On the other hand, the trip was aimed at exploration of the visa-free procedures, which was summarised and analysed in this article. It was also made in order to have not only official information about border-crossing procedures, as well as in order to investigate the real situation gathering our own experience, impression and feelings.

\section{The significance of the Polish-Belarusian borderland to tourism}

The Polish-Belarusian border features significant tourist attractions. From the point of view of the cultural heritage, and for Polish tourists in particular, this is an area associated with the Commonwealth of Two Nations that existed between the 16th and 18th centuries and in particular linked the lands of what today are Poland, Belarus, Lithuania, Latvia and other countries [25]. Thus, for example, the architectural heritage of the city of Grodno includes many key political events from Polish history, thanks to sittings of the former polity's Parliaments there. Grodno was also home to many famous Poles, including even kings like Stefan Batory, as well as scientists and artists (Eliza Orzeszkowa, etc.) From a religious point of view, Hrodna Region includes the Orthodox Church of Saints Boris and Gleb, while there are other, fortified churches elsewhere on the Belarusian side, as well as in Poland and Lithuania, with the Orthodox Churches of the Nativity in Murovanka and of St. Michael the Archangel in Synkavichy included among items of built and cultural heritage in Belarus [26, 27]. Brest Region, in turn, includes wooden churches of Polesie featuring on the preliminary UNESCO list [28].

The Białowieża Forest (i.e. Puszcza Białowieska in Poland and the Belovezhskaya Pushcha on the other side of the border) was a place for royalty and the aristocracy to hunt from the Middle Ages onwards. Among notables were the Tsars of Russia, and indeed the present Polish-Belarusian borderland area was part of the Russian Empire from 1815 through to 1917, only for western regions of today's Belarus to come within the Eastern Lands of the 2nd Republic of Poland in the 1921-1939 period. It was only after World War II that the border now separating Poland from Belarus (and then the People's Republic of Poland from the USSR, or specifically the Byelorussian SSR) was put in place, following the so-called Curzon Line [29]. Perhaps unexpectedly, given the then circumstances, this border proved something of a "Curtain" (rather inflexible, if not quite of iron), given that it separated Soviet totalitarianism from at least (at times) somewhat gentler regimes of Central and Eastern Europe. Therefore, there was an almost total lack of cross-border contacts for around half a century through to the early 1990s, when the border finally opened, and it proved possible to introduce a nonvisa regime [12, 30]. 
The border in question runs for $418.24 \mathrm{~km}$, which means $13.6 \%$ of the entire length of Poland's land border, as well as $10.5 \%$ of the border of Belarus as a landlocked state. As noted, the border is the heritage of the USSR and did not change when that polity finally fell. However, the 2007 joining by Poland and a number of the other CEECs to the EU's Schengen Zone ensured that Poland's eastern border was - even more than after the 2004 EU accession - an external frontier of the European Union. The effect was actually to hinder cross-border relations, at the local scale in particular. In fact, the border broke down a newly-established and still rather weak supranational network of economic, social and cultural links with Ukraine and Belarus, and indeed with Russia, while making any cross-border cooperation more difficult [7, 17-19, 31, 32].

For some years, the need to obtain a Belarusian visa represented a major obstacle to crossing of the border [19]. In fact, it is true to say that most facilities - especially hotels - offering overnight stays (not least those at Białowieża) could help to obtain a visa after a delay of perhaps just 3-4 days. However, that still left Polish tourists staying for a weekend (even a long weekend) unable to include a trip over to Belarus in their itineraries. Equally, border crossings of a specific nature are those allowing traversal on foot, or by water, as these are mainly or exclusively orientated at servicing tourists. Two of the river border crossings in operation are at the Polish-Belarusian and Lithuanian-Belarusian borders, and they mainly serve the water route leading via the Augustów Canal (in the case of Rudawka-Lesnaya), and further north the River Neman into Lithuania (at the PrivalkaŠvendubrè crossing).

\section{The Augustón Canal and Rudawka-Lesnaya border crossing}

The crossing on the Augustów Canal linking tributaries (and hence the overall systems) of the Rivers Vistula and Neman was built by the Tsarist authorities in the 1820s and 30s, in order to take grain and timber to the Baltic via the Neman, while bypassing Prussia. The overriding reason for the undertaking lay in a customs war between Russia and Prussia, which had in fact ended before construction work on the Canal finished. Indeed, by the end of the 19th century, the Canal had lost any transport significance it might have had, as the rail network then developed fast. The consequence was economic neglect, to which were added the destructive effects of the Second World War, which ruined several locks, bridges and other infrastructure.

However, both before and after the opening of the Rudawka-Lesnaya crossing, a general renovation of the Canal was carried out, with locks and other installations repaired on both sides of the border, in such a way that possibilities for the development of crossborder tourism by canoe were facilitated.

The Belarusian stretch of the Augustów (i.e. Augustovsky) Canal and adjacent areas include more than 50 natural and cultural attractions [33]. First and foremost, there is Grodno Forest Reserve, which also forms part of the Augustovsky Canal Recreational and Tourist Park founded in 2011. This is the area best suited to active holidaymaking and health tourism. Equally, where cultural heritage is concerned, areas along the Canal include many items of architectural heritage, notably churches built in the 18th and 19th centuries, graves of insurgents who rebelled against the Tsarist authorities in 1830 and again in 1863, bunkers from the times of the two World Wars, the Border Guard Museum and the Canal Museum, cemeteries of historical importance in Sapotskin and Selivanovtsy, and so on [14].

Furthermore, the area in which the borders of Belarus, Poland and Lithuania meet long offered a unique example of multiculturalism and multiple religions, being home to Byelorussians, Poles, Lithuanians, Jews, Ukrainians, Tartars, Roma and other nations, 
mostly in a position to cultivate their own traditions [30]. The Augustów Canal is regarded as a historic monument [34]. The land along it has highly valuable natural features, given the resources of both water and forest, as well as the inclusion of two transboundary areas, i.e. the Bug Euroregion and the transboundary functional sub-region of the Augustów Forest and Augustów-Grodno [12, 16, 35].

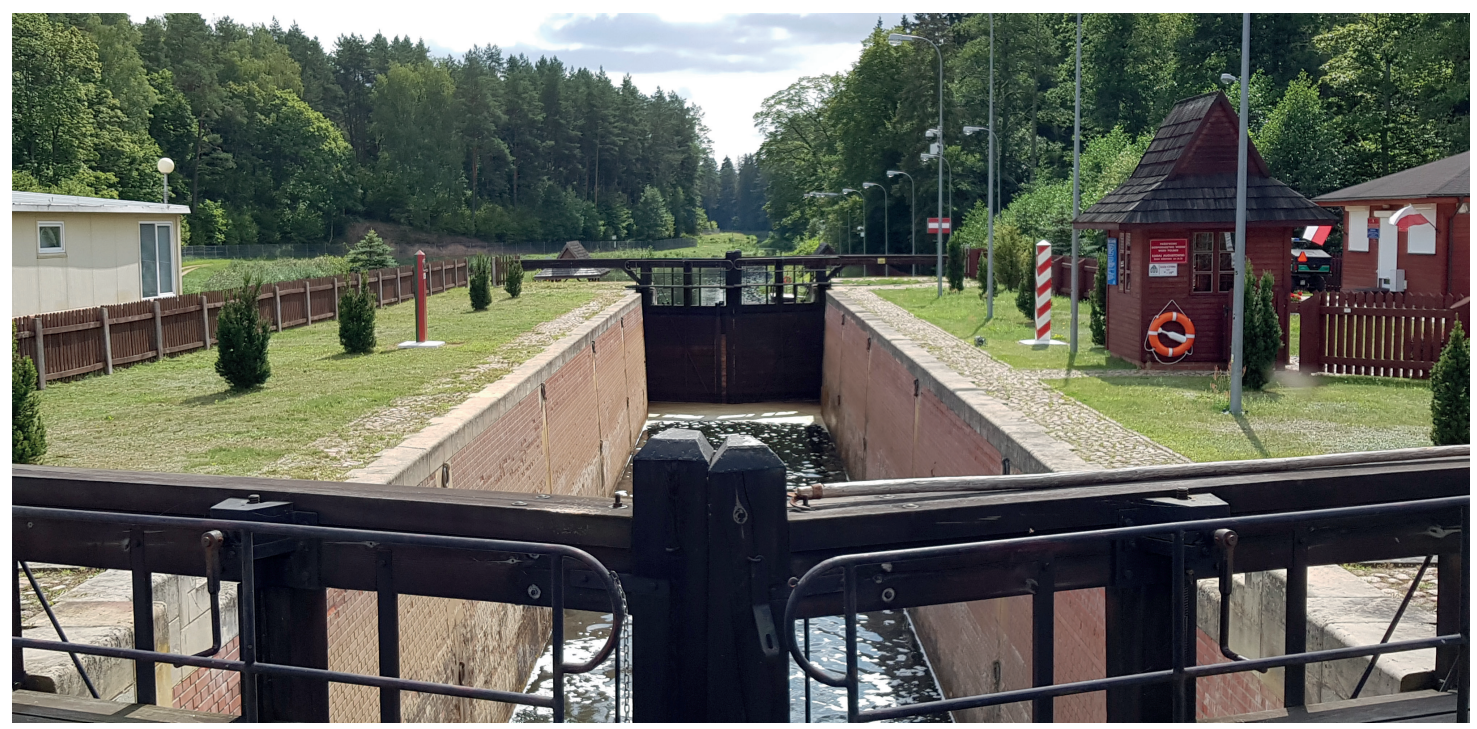

Fig. 1. Kurzyniec Lock as a border crossing. The border between Poland and Belarus runs along the axis of the Lock, and further along the Canal for some $3.5 \mathrm{~km}$

The Rudawka-Lesnaya border crossing is within the Polish gmina (local-authority area) of Płaska, poviat (county) of Augustów and voivodeship (province-region) of Podlaskie. Beyond the border, it is in Belarus's Grodno (Hrodna) district and region, and the Selsoviet (rural area) of Sapotskin. Kurzyniec Lock is in fact the 15th such installation along the Canal (counted from the Biebrza end, i.e. the west). The Lock lies not far from the village of Rudawka. Construction began in 1828 under Lt. Konstanty Jodko, though the 1829 completion of the work was achieved by Second-Lieutenant of Engineers F. Wielhorski. The name derives from the former village of Kurzyniec located on the far side of the Canal. The Lock was non-operational from 1939 onwards, having been much-damaged. However, under an agreement between the Governments of the Republics of Poland and Belarus (concluded on March 8th, 2005 in Augustów), the border section of the Canal underwent a renovation lasting from autumn 2006 through to June the following year. The sides of the Lock are linked by a bridge built of four concrete slabs. A border crossing for tourists is in operation here in the summer season.

That crossing (Rudawka-Lesnaya) was opened on April 30th, 2005, by virtue of a Governmental Declaration [15]. It is unique, being Poland's only border crossing along a river; and it is in operation seasonally (from 01 May do 01 October), between 7:00 and 19:00. Since the time of its opening, the only form of traffic permitted here is individual, and at the outset solely in a waterborne means of transport. Later, however, (from 28 April 2017 onwards), the possibilities for tourism were increased and diversified through a change in the nature of the crossing from purely aquatic to include also foot or cycle traffic by the side of the Canal [36].

The main problem with achieving growth in tourist traffic from the Polish side via the Rudawka-Lesnaya crossing (apart from the renovation work still continuing several years on from the opening) entailed obstacles of a formal nature, in general linked with the 
need for people to be in possession of a Belarusian visa. Apart from the cost of the visa in the range 25-120 euros depending on how many crossings of the border are required, how quickly the document needs to be obtained, and whether or not the services of a socalled "visa centre" are used -major further issues concerned the need to justify a stay, and the waiting time of up to 2 weeks [37]. A watershed moment thus came with the October 26th 2016 entry into force of Decree No. 318 of the President of the Republic of Belarus, which established a zone of visa-free visits for the citizens of some 70 states (including Poland) - who might spend up to 5 days in the so-called Augustovsky Canal Recreational and Tourism Park, which is taken to include both areas along the Canal as such and the city of Grodno.

Further steps towards the easing of the border regime in a visa-free direction were provided by extensions of both the area covered and the number of days' stay that might be spent in it. Under successive Decrees of the President Nos. 462 (dated 26.12.2017) and 300 (dated 07.08.2019), the periods of stay available to foreigners rose to 10 days (from January 1st 2018 onwards), and then to 15 (from November 10th 2019) [38, 39]. In turn, the easing of the regime regarding the circumstances in which the border could be crossed entailed the possibilities of coming by bicycle or on foot, and thus helped greatly increase the numbers of foreign tourists (including Poles) making use of the RudawkaLesnaya river border crossing [12]. Nevertheless, foreigners seeking to go into the visafree zone still need to be in possession of a pass prepared by a tourist agency, along with tickets for visits to at least two tourist attractions (museums and so on), medical insurance and a budget of around 20 euros for each day of stay. Although these requirements may be met readily online at the latest just one day before a visit, the preparation process is still somewhat complicated and bureaucratic in this way.

Belarusians also face major obstacles to any more-intensive tourist traffic via the border crossing indicated. Some of these are of infrastructure-related - like the lack of a direct surfaced road to the crossing, with a car park and the ban on crossing the border by recreational canoe in place on the Belarusian side (from the jetty near the Dombrovka Lock). However, the main problem is the requirement that a valid visa for Poland (or some other state within the Schengen Zone) be first obtained, with all the burdens that denotes in relation to:

- time (given the real difficulties that sometimes arise with registration "queues" during holidays periods, on account of this procedure being dominated by intermediary firms, in such a way that the time spent waiting for a visa is extended to between 2 and 4 weeks);

- accessibility (given the way that the consular institution in Grodno has - since December 1st 2014 - been catering, not only for inhabitants of Hrodna Region, but also for all citizens of Belarus) [40];

- finance (given that, from February 2nd 2020, the cost of a visa actually increased from 60 to 80 euros) [41] - there is nevertheless a chance of ratification for a bilateral Belarus-EU accord - entering into force in June 2020 at the earliest - which will ease the Schengen regime, with a visa costing 35 euros being fast-tracked [42] (at the same time, the dominance of so-called "visa centres" that act to block online and phone registrations for visa queues and require payment of an extra (\$30-60) fee for their intermediary services encourage the raising of the final prices of visas) [43].

The abolition of the so-called C ("shopping") visa from 2nd January 2019, making it more difficult to ascertain the purpose of travel to Poland [44] (with this type of visa previously being very popular among the inhabitants of border areas, including Hrodna region).

When it comes to the infrastructure of the Rudawka-Lesnaya crossing, it should be noted 
that this is now in a very good state following the renovation of the Augustów Canal. This was verified by means of participant observation in the course of summer 2019 fieldwork. On the Polish side, the crossing is reached from the Augustów area via road 672. There is a car park just before the crossing, while the border as such is in the middle of Kurzyniec Lock. There are buildings for Border Guard and Customs officials on both sides of the border, as well as a jetty for canoes and other small vessels. The whole area is monitored, and tourists approaching the crossing on the water, by bicycle or on foot are all checked by officers immediately. However, checks on those on the water take place without any necessity for them to step out onto land.

On the Belarusian side, there is a local gravel road only allowing transit by bicycle or on foot, with this leading several kilometres along the Canal and passing the Valkushyk Lock before local road H-6541 is eventually reached. This route represents a prolongation into Belarus of the Polish network of cycle paths known as Wschodni Szlak Rowerowy Green Velo (the Green Velo East of Poland Cycling Trail); and it is marked out appropriately and leads towards the Dombrovka Lock and even to Grodno itself [33]. A major step towards the lengthening and development of the water route came as the Lithuanian-Belarusian border along the River Neman gained what was essentially a "twin" of the RudawkaLesnaya crossing - between Privalka and Švendubrè. This operates in the same hours of the summer season and makes it possible for lovers of canoeing to navigate along the Augustów Canal, before continuing through Lithuania along the Neman (Nemunas), even as far as the Baltic Sea.

The less-stringent crossing of the border together with the emergence of possibilities to cycle or hike beside the Canal absolutely ensured a far greater number of foreign tourists (including from Poland) taking advantage of the visa-free regime. This is reflected in a most tangible way by exclusively tourism-related data on the use of the Rudawka-Lesnaya border crossing by river (Fig. 2).

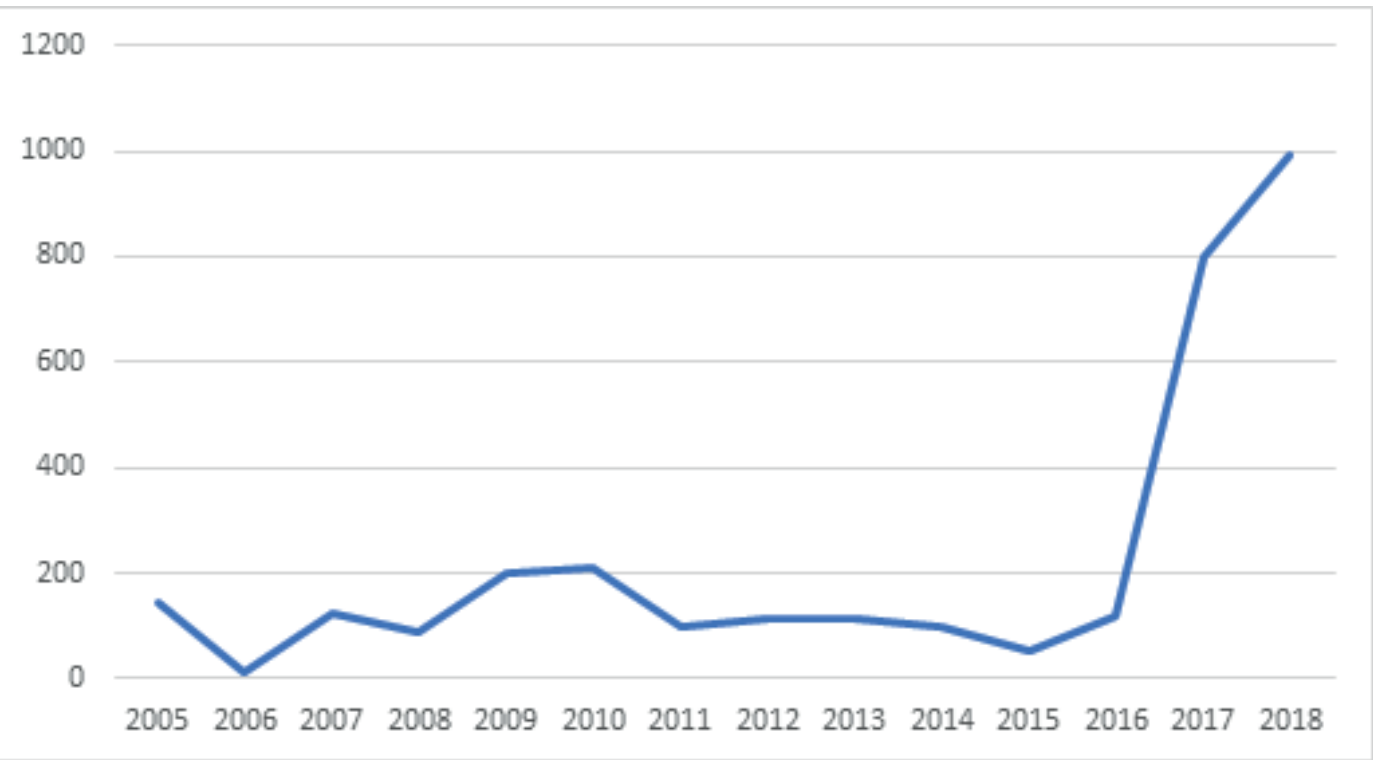

Fig. 2. Numbers of citizens of the Republic of Poland crossing the border in the direction of Belarus in the 20052018 period, via the Rudawka-Lesnaya river border crossing.

Source: authors' own elaboration based on data from Poland's Border Guard (Straż Graniczna) 


\section{DISCUSSION}

During the research of the Augustów Canal in terms of cooperation on the tri-border area of Poland, Belarus and Lithuania, it would be worth discussing the problem of inequality in the cross-border cooperation of participants. The imbalance of cooperation on the tripoint also depends on key cities located nearby as well as their power and specifications, which in a real way affects the development of tourism on the Augustów Canal. In our case, the city of Grodno absolutely dominates with 370,000 inhabitants. In contrast, Druskininkai in Lithuania and Augustów in Poland are small towns specializing in spa and water tourism (sailing, kayaking) respectively. There are the least controversial divisions of triple points - with different cross-border functions or with one dominant function (e.g. cross-border territorial unit of nature protection) [20]. In our case, we could observe the cooperation with different cross-border functions. The main factor influencing the activation of cooperation in the area of the tripoint of Poland, Belarus and Lithuania are the water routes, the supreme role in this connection plays the Augustów Canal. Further factors are related to regional and cross-border cooperation, transport and nature protection.

Another controversial question is the issue of the growing importance of the Augustów Canal through the development of ecotourism and the introduction of a visa-free zone. In recent years, this process has still been characterized by positive features like an increase in the number of tourists, border regime easing, infrastructure improvement etc. [12, 19, $22,33]$. Nevertheless, there are such challenges and threats as the saturation of the tourist market - all lovers of canoeing and ecotourism will already visit this area, which in reality will hinder the increase in traffic and tourism development. Other negative factors may include a significant deterioration of political relations of Belarus with the European Union after mass repression during the election campaign in Belarus in May - August 2020, as well as the consequences of the COVID-19 pandemic. On the other hand, the threats of COVID-19 may in the future be a stimulus for the development of peripheral ecotourism "on a clean surface", which may become an interesting topic for further research on the transformation of the Augustów Canal.

\section{CONCLUSIONS}

Processes of political change have caused "re-internalisation" of tourism [45], but also in border regions in particular -so-called "cross-borderisation" of tourism - in the sense of it being made more transboundary in character [2]. This reflects - and also further enhances - both cross-border traffic and cross-border cooperation [3, 21, 30, 46]. Tasks more fully compatible with sustainable development then become pursuable, and best practices and solutions are implemented (e.g. Greenway Trails, and the use of canoe routes such as the Augustów Canal), with consequences including the promotion of natural and cultural heritage.

The issues discussed here relate to the European Union's external frontier, but at the same time to the close proximity of a state that had until recently limited its international contacts (and the possibilities for citizens of other countries to come on to its territory). The inclusion within non-visa travel of such large cities as Grodno had an obvious impact in diversifying what is available to tourists in this wider region, also concerning transport and accommodation infrastructure, health-resort opportunities, and so on. An exceptional example highlighting changes and good practice is offered by tourism development along the Augustów (Augustovsky) Canal, whose significance has increased in recent years, as it has become accessible either side of the Polish-Belarusian border, and as the new (Rudawka-Lesnaya) border crossing at Kurzyniec Lock has opened. The step-by-step (5year) introduction by state authorities of visa-free regimes and zones undoubtedly produced 
a major dynamising effect where Belarus-bound Polish tourist traffic is concerned. The overriding factor triggering a steady enlargement of tourist space - and utilisation thereof on either side of the border - has been the founding since November 2019 of the uninterrupted, visa-free tourist corridor known as the "Brest-Grodno space". This has made possible the obstacle-free visiting of part of western Belarus, especially along the north-south axis. A remaining negative factor is the still-inflexible external frontier between the EU and Belarus, as well as the need for various formalities to be complied with (like the possession of passes, border checks, and so on).

\section{REFERENCES}

[1] Timothy DJ. Tourism and political boundaries, Routledge Advances in Tourism. London and New York; 2001.

[2] Więckowski M. Tourism development in the borderlands of Poland. Geographia Polonica. 2010;83(2):67-81. doi. org/10.7163/GPol.2010.2.5

[3] Mayer M, Zbaraszewski W, Pieńkowski D, Gach G, Gernert J. Barrier effects of the Polish-Germanborder on tourism and recreation: The case of Protected Areas. An Introduction. In: Cross-border tourism in Protected Areas. Geographies of tourism and global change. Springer, Cham; 2019. 1-17. https://doi.org/10.1007/978-3-030-05961-3

[4] Stepanova SV. The Northern Ladoga region as a prospective tourist destination in the Russian-Finnish borderland: Historical, cultural, ecological and economic aspects. Geographia Polonica. 2019;92(4):409-428. https://doi. org/10.7163/GPol.0156

[5] Scot JW. Border politics in Central Europe: Hungary and the role of national scale and nation-building. Geographia Polonica. 2018;91(1):17-32. https://doi.org/10.7163/GPol.0101

[6] Bar-Kołelis D, Wendt J. Comparison of cross- border shopping tourism activities at the Polish and Romanian external borders of European Union. Geographia Polonica. 2018;91(1):113-125. https://doi.org/10.7163/GPol.0103

[7] Dołzblasz S. A network approach to transborder cooperation studies as exemplified by Poland’s eastern border. Geographia Polonica. 2018;91(1):63-76. https://doi.org/10.7163/GPol.0091

[8] Anderson J, O'Dowd L, Wilson TM. Why study borders now? In: O'Dowd L, Anderson J, Wilson TW, eds. New Borders for a Changing Europe: Cross-Border Cooperation and Governance. Routledge; 2002, 1-12.

[9] Ramutsindela M, editor. Cartographies of Nature: How Nature Conservation Animates Borders, New Castle upon Tyne: Cambridge Scholars; 2014.

[10] Więckowski M. Political borders under ecological control on the Polish borderlands. Geographia Polonica. 2018; 91(1):127-138. https://doi.org/10.7163/GPol.0105

[11] Więckowski M, Saarinen M. Tourism transitions, changes, and the creation of new spaces and places in CentralEastern Europe. Geographia Polonica. 2019;92(4):369-377. https://doi.org/10.7163/GPol.0154

[12] Więckowski M, Cyargeenka A. Wpływ złagodzenia reżimu granicznego na Białorusi na wielkość ruchu turystycznego - wstęp do badań [The influence of relaxation of the border regime in Belarus on tourist traffic - introduction to the research]. Przegląd Geograficzny. 2019;91(4):589-608. Polish. https://doi.org/10.7163/PrzG.2019.4.8

[13] Yeliseyeu A. Die neue Visaregelung. Langsam und mit Einschränkungen öffnet sich Belarus Reisenden aus dem Westen. Belarus-Analysen. 2017;32:2-6. https://doi.org/10.31205/BA.032.01

[14] Kul-Sialverstava S. Pamięć historyczna mieszkańców pogranicza białorusko-polskiego [Historical memory of the inhabitants of the Belarusian-Polish borderland]. In: Snarski K, Żulpa A, editors. W krainie wielu tradycji. Badania etnograficzne na pograniczu polsko-litewsko-białoruskim w XX i początkach XXI wieku, Suwałki; 2014 . Polish.

[15] Bogusz T, Sialverstava S. Wielokulturowość polsko-białoruskiego pogranicza: aspekt turystyczny [Multiculturalism of the Polish-Belarusian borderland: the tourist aspect]. In: Sialverstava S, Roman A, Zuzda J, editors, Promocja turystyki na pograniczu polsko-białoruskim, Białystok; 2018, 69-78.

[16] Roman A, Sawośko K, Żendzian J, Niesteruk P. Motywy podróżowania na pograniczu polsko-białoruskim [Motifs of traveling on the Polish-Belarusian border]. In: Sialverstava S, Roman A, Zuzda J, editors. Promocja turystyki na pograniczu polsko-białoruskim, Białystok; 2018, 171-188. Polish.

[17] Komornicki T., (2010), Flows of persons and goods across the Polish segment of the outer boundary of the European Union - results of a research project, European Union external and internal borders - interactions and networks, Europa XXI. 2010;20:9-29. Warszawa: PAN IGiPZ. https://doi.org/10.7163/Eu21.2010.20.1

[18] Dołzbłasz S. Sieci współpracy transgranicznej na pograniczach Polski [Cross-border cooperation networks on the Polish border], Rozprawy Naukowe Instytutu Geografii i Rozwoju Regionalnego Uniwersytetu Wrocławskiego, 40, Wrocław: Wydawnictwo Uniwersytetu Wrocławskiego; 2017. Polish.

[19] Marin A. Of barriers, breaches and bridges; Cross-border ecotourism and the prospect of horizontal governance acting as a bridge in Belarus-EU Neighbourhood relations. In: Liikanen I, Scott JW, Sotkasiira T, eds. The EU's Eastern Neighbourhood. Migration, borders and regional stability, Routledge; 2017, 115-133.

[20] Kałuski S. Trójstyki granic politycznych. Zróżnicowanie cech i funkcji. Czasopismo Geograficzne. 2016;87(2):101-115.

[21] Timothy DJ, Saarinen J. Cross-border co-operation and tourism in Europe. In: Costa C, Panyik E, Buhalis D, eds. Trends in European tourism planning and Organisation. Bristol: Chanl view; 2013. https://doi.org/10.21832/9781845414122-009

[22] Marin A, From breach to bridge: the Augustów canal, an ecotourism destination across the EU's border with Belarus, Articulo. 2011. [Available at https://journals.openedition.org/articulo/1705] [Accessed on 10 June, 2020]. https://doi. org/10.4000/articulo.1705

[23] Perrier Bruslé L. The Borderas a aarker of territoriality: Multi-scalar perspectives and multi-agent processes in a South American Borderland Region. Geopolitics. 2013;18(3):584-611. https://doi:10.1080/14650045.2012.749242 
[24] Stoffelen A, Ioannides D, Vanneste D. Obstacles to achieving cross-border tourism governance: A multi-scalar approach focusing on the German-Czech borderlands. Ann Tourism Res. 2017;64:126-138. https://doi.org/10.1016/j. annals.2017.03.003

[25] Sienkiewicz W, Olczak E, editors. Historia Polski: Atlas Ilustrowany [History of Poland: Illustrated Atlas]. Warszawa: Demart SA; 2016. Polish.

[26] Miedwiediewa IW, editor. Turizm i turisticzeskije riesursy w Riespublikie Biełarus', Statisticzeskij sbornik. Minsk: Nacyonalnyj statisticzeskij komitiet Riespubliki Biełarus'; 2019, 19.

[27] Barwiński M, Wendt JA. National minorities in Polish politics and its eastern neighbors. Kesit Academy Journal, 2018;1(1):22-36

[28] UNESCO, Belarus, 2020 [Available at http://whc.unesco.org/en/statesparties/by] [Accessed on 28 April, 2020]. https:// doi.org/10.18356/3b269b40-en

[29] Eberhardt P. Granice polityczne Polski i jej sąsiadów w XX wieku (wybrane zagadnienia) [Political borders of Poland and its neighbors in the 20th century (selected issues)]. Kraków: Polskie Towarzystwo Geopolityczne; 2018. Polish.

[30] Kolosov V, Więckowski M. Border changes in Central and Eastern Europe: An introduction. Geographia Polonica. 2018;91(1):5-16. https://doi.org/10.7163/GPol.0106

[31] Komornicki T, Miszczuk A. Eastern Poland as the borderland of the European Union. Quaestiones Geographicae. 2010;29(2):55-69. https://doi.org/10.2478/v10117-010-0014-5

[32] Jakubowski A, Miszczuk A, Kawałko B, Komornicki T, Szul R. The EU’s New Borderland. Cross-border relations and regional development. Oxon-New York: Routledge; 2017. https://doi.org/10.4324/9781315622873

[33] Sialverstava S, Bogusz T, Roman M. Tourism development in the Belarusian part of the Augustow Canal. Turystyka i Rozwój Regionalny. 2018;9:63-70. https://doi.org/10.22630/TIRR.2018.9.7

[34] Internetowy System Aktów Prawnych [Internet System of Legal Acts]. Polish [Available at http://prawo.sejm.gov.pl] [Accessed on 28 April, 2020].

[35] Suliga J. Polsko-białoruska współpraca przygraniczna w dziedzinie planowania przestrzennego [Polish-Belarusian cross-border cooperation in the field of spatial planning]. In: Miszczuk A, Wiśniewski R, editors. Informacyjnoinfrastrukturalne uwarunkowania współpracy transgranicznej, Tom 2, Norbertinum, Lublin; 1996. Polish.

[36] Straż Graniczna [Border guards]. Kajakiem, pieszo bądź rowerem na Białoruś. 2017 [Available at https://podlaski. strazgraniczna.pl/pod/aktualnosci/22080,Kajakiem-pieszo-badz-rowerem-na-Bialorus.html] [Accessed on 28 April, 2020]. Polish.

[37] Białoruś bez wizy [Belarus without a visa], Polish [Available at https://www.wizaserwis.pl/Bialorus?gclid=EAIaIQob ChMIwYztpqyc5wIVjoeyCh1pBA99EAAYAiAAEgJa4fD_BwE] [Accessed on 28 April, 2020].

[38] Natsional'nyy pravovoy Internet-portal Respubliki Belarus'. [Available at http://pravo.by/ ] [Accessed on 28 April, 2020].

[39] Ofitsial'nyy Internet-portal Prezidenta Respubliki Belarus'. [Available at http://president.gov.by/] [Accessed on 28 April, 2020].

[40] Posol'stvo Pol'shi otmenilo dlya belorusov territorial'nyy printsip podachi dokumentov na vizu. 2014 [Available at http:// tomin.by/news/granica/9251-posolstvo-polshi-otmenilo-dlya-belorusov-territorialnyj-printsip-podachi-dokumentovna-vizu] [Accessed on 28 April, 2020].

[41] Predstavitel'stvo ES: «Zamorozit'» vizy na urovne 60 yevro nevozmozhno, 2020 [Available at https://news.tut.by/ economics/669886.html] [Accessed on 28 April, 2020].

[42] Belarus' i ES podpisali soglasheniye ob uproshchenii vizovogo rezhima, «shengenu» za 35 yevro byt'. No v iyune, 2020 [Available at https://news.tut.by/economics/667845.html] [Accessed on 28 April, 2020].

[43] «Za den' zvonil sotni raz!» Posol'stvo otvechayet turistam, kotoryye zhaluyut'sya na vizovyy tsentr Pol'shi, 2020 [Available at https://news.tut.by/society/668168.html] [Accessed on 28 April, 2020].

[44] Do Polski na zakupy? Białorusinom będzie trudniej dostać wizę, 2018, [Available at https://belsat.eu/pl/news/dopolski-na-zakupy-bialorusinom-bedzie-trudniej-dostac-wize/] [Accessed on 28 April, 2020].

[45] Williams AM, Baláž V. International petty trading: Changing practices in Trans-Carpathian Ukraine. Int J Urban Region Res. 2002;26(2):323-342. https://doi.org/10.1111/1468-2427.00382

[46] Banaszkiewicz M, Graburn N, Owsianowska S. Tourism in (Post) socialist Eastern Europe. J Tourism Cultural Change. 2017;15(2):109-121. https://doi.org/10.1080/14766825.2016.1260089 